\title{
Hepatit Delta Virüsü Enfeksiyonu Seroprevalansının Retrospektif Olarak Değerlendirilmesi
}

\section{Retrospective Evaluation of Hepatitis Delta Virus Infection Seroprevalence}

Tevhide Ziver Sarp ${ }^{1}$, Harika Öykü Dinç², Doğukan Özbey ${ }^{3}$, Seher Çelik Akkuş³, Merve Cihan ${ }^{3}$, Beyza Aslan $^{3}$, Rüveyda Akçin ${ }^{3}$, Nesrin Gareayaghi ${ }^{4}$, Mert Ahmet Kuşkucu ${ }^{3}$, Kenan Midilli ${ }^{3}$, Bekir Kocazeybek ${ }^{3 *}$

${ }^{1}$ Doğu Akdeniz Üniversitesi, Sağlık Bilimleri Fakültesi, Beslenme ve Diyetetik Anabilim Dalı, Gazimağusa, K.K.T.C.

${ }^{2}$ Bezmialem Vakıf Üniversitesi, Eczacılık Fakültesi, Farmasötik Mikrobiyoloji Anabilim Dalı, İstanbul, Türkiye ${ }^{3}$ İstanbul Üniversitesi, Cerrahpaşa, Cerrahpaşa Tıp Fakültesi Tıbbi Mikrobiyoloji Anabilim Dalı, İstanbul, Türkiye ${ }^{4}$ Sağlık Bilimleri Üniversitesi, İstanbul Şişli Hamidiye Etfal Eğitim Araştırma Hastanesi, Kan Merkezi, İstanbul, Türkiye

email: tevhide_ziver@hotmail.com, oykudinc@gmail.com,dogukanozbey@gmail.com,dr.seher@hotmail.com, merve.cihan@iuc.edu.tr, aslanbeyza1999@gmail.com, ruveydaakcin@gmail.com, nesringareayaghi@hotmail.com, kuskucum@gmail.com,kmidilli@gmail.com,bzeybek@istanbul.edu.tr

ORCID: 0000-0002-7338-1292

ORCID: 0000-0003-3628-7392

ORCID: 0000-0002-0596-1551

ORCID: 0000-0002-9236-2062

ORCID: 0000-0002-0075-051X

ORCID: 0000-0001-5986-4645

ORCID: 0000-0002-6993-0383

ORCID: 0000-0002-0812-1128

ORCID: 0000-0001-8735-5725

ORCID: 0000-0003-3007-3422

ORCID: 0000-0003-1072-3846

*Sorumlu yazar/Corresponding Author: Bekir Kocazeybek

Gönderim Tarihi / Received: 24.03.2021

Kabul Tarihi / Accepted: 17.05.2021

DOI: 10.34087/cbusbed.901563

\section{$\ddot{O} \mathbf{z}$}

Giriş ve Amaç: Hepatit Delta Virüsü, Hepatit B virüs varlığında koenfeksiyon, süperenfeksiyon ve kronik hepatit delta enfeksiyonu yapabilen defektif bir virüstür. Bu çalışmada, Ocak 2014-Eylül 2019 tarihleri arasında İstanbul Üniversitesi-Cerrahpaşa, Cerrahpaşa Tıp Fakültesi Mikrobiyoloji Laboratuvarına HBV ve/veya HDV enfeksiyonu şüphesi ile başvuran olgularda retrospektif olarak HDV enfeksiyonu seroprevalansının belirlenmesi amaçlanmıştır. Gereç ve Yöntemler: Ocak 2014-Eylül 2019 tarihleri arasında HBV ve/veya HDV enfeksiyon şüphesi ile başvuran 1374 hasta kanında $\mathrm{HBsAg}$, anti-HBc IgM, anti $\mathrm{HBc}$ (total) $\mathrm{HBeAg}$, anti $\mathrm{HBe}$, anti $\mathrm{HBs}$, anti HDV, HBV DNA ve HDV RNA test sonuçları olarak değerlendirilmiştir.

Bulgular: Çalışmaya alınan HBV tanılı 1374 hastanın yaşları 8-87 arasında olup, 585'inin(\%42.6) kadın, 789'unun(\%57.4) erkek olduğu belirlenmiştir. Yapılan analizler sonucunda 1374 hastanın \%7.9'unda anti HDV pozitifliği saptanmıştır. 2014 yılında pozitif saptanan hastaların \%1.2'sinin akut HBV, \%27.3'ünün kronik HBV ve \%5.7'sinin inaktif taşıyıcı olduğu belirlenmiştir. 2015-2019 yılları arasında pozitif saptanan hastaların ise \% 7.2'sinin akut HBV, \%8.3'ünün kronik hepatit ve \%9.9'unun kronik enfeksiyonu olduğu belirlenmiştir. Anti HDV pozitif saptanan olgular içerisinde kadın bireylerde anti-HDV pozitifliği erkeklere göre anlamlı düzeyde yüksek bulunmakla birlikte $(\mathrm{p}<0,05)$, yaş grupları arasında istatistiksel olarak anlamlı düzeyde fark olmadığı saptanmıştır. 
Sonuç: Çalışma sonuçlarımız son yıllarda batı bölgesinde yapılan prevalans çalışmalarının sonuçlarına benzer bulunmakla birlikte, anti HDV prevalansının az da olsa yükseliş eğiliminde olduğunu göstermektedir. Güncel prevalans verilerinin ortaya koyulabilmesi için geniş çaplı çalışmalar yapılması gerektiğini düşünmekteyiz.

Anahtar kelimeler: HDV, HDV seroprevalans1, Koenfeksiyon, Süperenfeksiyon

\section{Abstract}

Objective: Hepatitis Delta Virus is a defective virus that can cause co-infection, superinfection and chronic hepatitis delta infection with Hepatitis B Virus. In this study, it was aimed to retrospectively determine the seroprevalence of HDV infection in patients who applied to Istanbul University-Cerrahpaşa, Cerrahpaşa Medical Faculty Microbiology Laboratory with suspected HBV and / or HDV infection between January 2014 and September 2019.

Material and Method: HBsAg, anti-HBc IgM, anti HBc (total) HBeAg, anti HBe, anti HBs, anti HDV, HBV DNA and HDV RNA test results were evaluated in the blood of 1374 patients who were admitted with the suspicion of HBV and / or HDV infection between January 2014 and September 2019.

Results: The age range of 1374 patients diagnosed with HBV was to 8 to 87 years and 585(\%42.6) were female and 789(\%57.4) were male. As a result of the analysis, anti HDV positive was detected in $7.9 \%$ of 1374 patients. In 2014, it was determined that $1.2 \%$ of the patients with positive were acute $\mathrm{HBV}, 27.3 \%$ were chronic $\mathrm{HBV}$ and $5.7 \%$ were inactive carriers. Between 2015-2019, it was determined that $7.2 \%$ of the patients with positive were acute HBV, $8.3 \%$ had chronic hepatitis and $9.9 \%$ had chronic infection. Although anti-HDV positive was significantly higher in females than males ( $<<0.05$ ), it was found that there was no statistically significant difference between age groups.

Conclusion:Although our study results are similar to the results of prevalence studies conducted in the western region in recent years, they show that the prevalence of anti HDV is in an upward trend, albeit slightly. We think that largescale studies should be conducted in order to reveal current prevalence data.

Keywords: Coinfection, HDV, HDV seroprevalance, Superinfection

\section{Giriş}

Hepatit Delta Virüsü(HDV), 1977 y1lında ilk kez Rizetto ve ark. tarafından İtalya'nın Torino şehrindeki kronik Hepatit B Virüs(HBV) enfeksiyonlu bir olgunun hepatosit çekirdeklerinde, delta antijeni ve hastanın serumunda bu antijene karşı oluşan antikorun varlığının tespit edilmesi sonucu ortaya çıkarılmıştır[1]. HDV, tek zincirli, sirküler, RNA virüsü olup, taksonomide satellit virüsler içerisinde kabul edilmektedir. HDV, replikasyon bakımından defektif bir virus olup, virus partikülünün diseminasyonu için HBV'nin yüzey antijenine(HBsAg) ihtiyaç duymaktadır. $\mathrm{Bu}$ sebeple HDV enfeksiyonu, HBsAg pozitif olan bireylerde görülmektedir[2].

HDV, HBV'ye benzer şekilde, parenteral, horizontal, vertikal ve cinsel yol ile bulaşmaktadır. HDV, HBV ile birlikte, koenfeksiyon, süperenfeksiyon ve kronik enfeksiyon olmak üzere üç farklı klinik seyir göstermektedir. Koenfeksiyon, HBV ve HDV'nin kişiyi ayni anda enfekte etmesi ile ortaya çıkan eşzamanlı bir klinik bir tablodur. Buna karşılık süperenfeksiyon kronik HBV enfeksiyonu olan hastada takiben HDV enfeksiyonunun gelişmesi olarak tanımlanıp, yüksek oranda kronikleşme ve fulminan hepatit gelişmesine sebep olup, hepatit tablosunu ağırlaştırmaktadır. Kronik Hepatit Delta ise, viral hepatitlerin en şiddetli formu olup, siroz ve hepatoselüler karsinom gelişimini hızlandırmaktadır[3, 4].

HDV, tüm dünyada görülebilen, ancak farklı coğrafyalarda prevalans, insidans ve klinik özellikleri değişkenlik gösteren bir etkendir[5, 6].Dünya çapında yaklaşık 20 milyon kişinin HDV ile enfekte olduğu tahmin edilmekle birlikte son y1llarda uygulanan etkili
HBV aşılaması ile enfeksiyonunun görülme sıklığının azalış gösterdiği bildirilmektedir[7]. Akdeniz ülkeleri, Afrika ve Güney Amerika'nın Amazon bölgesi HDV için yüksek endemik bölgeler iken, Türkiye orta endemik bölgeler arasında yer almakta ve bölgelere göre \%16-33 arasında değişen HDV prevalansı saptanmaktadır[6, 8, 9]. Her ne kadar son yıllarda ülke genelinde $\mathrm{HBV}$ ve HDV prevalansı düşüş gösterse de Doğu ve Güney Doğu Anadolu Bölgelerinde HDV Batı bölgelerine göre halen önemli sağlık problemleri arasında yer almaktadır[10]. HDV enfeksiyonu, HBsAg testi pozitif olan bireylerde delta antijenine karşı oluşan antikorların saptanması (Anti HDV) ve takibinde HDV RNA tespiti ile belirlenmektedir[7]. Son yıllarda insan hareketliliğinin çok olduğu, sık göç alan ve sosyoekonomik dengesizliğin yoğun olduğu metropol şehir olan İstanbul'da HDV prevalansının belirlenmesi oldukça önemlidir.

Bu çalışmada Ocak 2014-Eylül 2019 tarihleri arasında İstanbul Üniveristesi-Cerrahpaşa, Cerrahpaşa Tıp Fakültesi Tıbbi Mikrobiyoloji Anabilim Dalı laboratuvarlarına klinik olarak HBV ve/veya HDV enfeksiyonu şüphesi ile başvuran olgularda retrospektif olarak HDV enfeksiyonu seroprevalansının belirlenmesi amaçlanmıştır.

\section{Materyal ve Metot}

Çalışmamız Ocak 2014-Eylül 2019 tarihleri arasında Cerrahpaşa Tıp Fakültesi Hastanesi'ne HBV ve/veya HDV enfeksiyon şüphesi ile başvuran ve T1bbi Mikrobiyoloji Ana Bilim Dalı Seroloji/ELISA ve Viroloji ve Moleküler Mikrobiyoloji Laboratuvarlarına gönderilen kan örneklerinde $\mathrm{HBsAg}$, anti-HBc IgM, anti 
$\mathrm{HBc}$ (total) $\mathrm{HBeAg}$, anti $\mathrm{HBe}$, anti $\mathrm{HBs}$, anti $\mathrm{HDV}, \mathrm{HBV}$ DNA ve HDV RNA test istemi yapılan 1374 hasta ile yürütülmüştür. Hastaların laboratuvar sonuçları İshop Otomasyon Kayıt Sistemi'nden retrospektif olarak elde edilmiştir.

2014 yılında hastanemize HBV ve/veya HDV enfeksiyon şüphesi ile başvuran hastalara ait HBV DNA test sonuçlarına elektronik ortamdan ulaşılamadığından ötürü bu dönemdeki hastalar, serolojik test sonuçlarına, alanin aminotransferaz(ALT) düzeyi ve karaciğer histolojilerine göre akut, kronik ve inaktif taşıyıcı olarak 3 gruba ayrılarak incelenmiştir.

2015-19 yılları arasında hastanemize HBV ve/veya HDV enfeksiyon şüphesi ile başvuran hastalar ise Avrupa Karaciğer Araştırmaları Derneği(EASL) 2017 Klinik Uygulama Kılavuzu'nda belirtildiği şekilde sınıflandırılmıştır. Bu sınıflamaya göre kronik hepatit B 5 ayrı faza ve kronik enfeksiyon/kronik hepatit olmak üzere 2 gruba ayrılmıştır. Kronik enfeksiyon ve kronik hepatit durumu; HBV DNA, HBsAg, ALT düzeyi, HBeAg pozitif/negatiflik durumu ve karaciğer histolojisine göre değerlendirilmiştir[11].

Hastalardan alınan serum örneklerinde HBV ile ilişkili; HBsAg, anti $\mathrm{HBc} \mathrm{IgM}$, anti $\mathrm{HBc}($ total), $\mathrm{HBeAg}$, anti $\mathrm{HBe}$, ve anti HBs testleri için GBC,General Biologicals Corporation, Taiwan test kitleri, HDV ile ilişkili; anti HDV testi için Dia.Pro, Diagnostic Bioprobes, Milano İtalya ticari kiti kullanılmıştır. Bu ticari kitler mikro ELISA cihazında (Triturus, Grifols, İtalya) üretici firmaların talimatlarına uygun olarak analiz edilmiştir.

Hastalardan alınan kan örneklerinde HBV DNA(Cobas AmpliPrep/COBAS TaqMan HBV test v.2, Roche Molecular Systems, ABD) ve HDV RNA(Fluorion HDV QNP 1.0 Real-Time PCR Kiti, Iontek) tespit etmek için Real Time PCR yöntemi kullanılmıştır.
Çalışmaya anti HDV testi pozitif saptanan 109 hasta dahil edilmiştir. Bunların sadece 84'ünün HDV RNA sonuçlarına elektronik kayıt sisteminde ulaşılabilmiştir. Araştırma verilerinin analizinde Statistical Package for Social Sciences (SPSS) 24.0 yazılımı kullanılmıştır. Verilerin analizinde frekans ve ki kare testi kullanılmış, $\mathrm{p}<0.05$ anlamlılık sınırı olarak kabul edilmiştir.

Bu çalışma İstanbul Üniversitesi Cerrahpaşa-Cerrahpaşa Tıp Fakültesi Klinik Araştırmalar Etik Kurulu'nun 20.07.2020 tarih ve 64414572-604.01.01-92771 say1l karar doğrultusunda "Etik Kurul Onayı" alınarak uygulanmıştır.

\section{Bulgular ve Tartışma \\ 3.1.Bulgular}

Bu çalışma, HBV ve/veya HDV şikayetleri ile Ocak 2014-Eylül 2019 tarihleri arasındaki 5 yıllık sürede hastanemize başvuran ve retrospektif olarak değerlendirilen 1374 hasta ile yürütülmüştür. Çalışmaya alınan HBV tanılı hastaların, yaşları 8-87 arasında olup, 585'inin(\%42.6) kadın, 789'unun(\%57.4) erkekti. HBsAg'si pozitif olan 1374 hastanın 109'unda (\%7.9) anti HDV pozitifliği saptanmıştır. Anti HDV pozitif saptanan 109 hastanın 84'ünün HDV RNA sonucuna ulaşılmış ve bu 84 hastanın antikor ve RNA sonuçlarının \%100 korele olduğu belirlenmiştir.

Araştırma kapsamına alınan 2014 yılına ait hastaların Klinik HBV gruplarında anti HDV pozitifliğinin cinsiyete ve yaş gruplarına göre dağılımı Tablo 1 'de verilmiştir. Tablo 1. incelendiğinde 2014 yılındaki hastaların klinik HBV gruplarında cinsiyete göre anti HDV pozitifliği oranları arasında istatistiksel olarak anlamlı düzeyde fark olmadığı saptanmıştır $(p>0,05)$. Yaş grubuna göre anti HDV pozitifliğinin karşılaştırılması ki kare testinin varsayımları sağlanamadığından dolayı yapılamamıştır(Tablo 1).

Tablo 1. 2014 Yılına Ait Hastaların Klinik HBV Durumlarına göre Anti HDV Pozitifliğinin Cinsiyete ve Yaşa Göre Dağılımı

\begin{tabular}{|c|c|c|c|c|c|c|c|c|c|c|c|c|c|c|c|c|c|c|}
\hline & \multicolumn{4}{|c|}{ Akut HBV } & \multicolumn{4}{|c|}{ Kronik HBV } & \multicolumn{4}{|c|}{ Inaktif } & \multicolumn{4}{|c|}{ Toplam } & \multirow[b]{3}{*}{$\mathbf{X}^{2}$} & \multirow[b]{3}{*}{$\mathbf{p}$} \\
\hline & \multicolumn{2}{|c|}{$\mathbf{P}$} & \multicolumn{2}{|c|}{$\mathbf{N}$} & \multicolumn{2}{|r|}{$\mathbf{P}$} & \multicolumn{2}{|r|}{$\mathbf{N}$} & \multicolumn{2}{|r|}{$\mathbf{P}$} & \multicolumn{2}{|c|}{$\mathbf{N}$} & \multicolumn{2}{|c|}{$\mathbf{P}$} & \multicolumn{2}{|c|}{$\mathbf{N}$} & & \\
\hline & $\mathbf{n}$ & $\%$ & $\mathbf{n}$ & $\%$ & $\mathbf{n}$ & $\%$ & $\mathbf{n}$ & $\%$ & $\mathbf{n}$ & $\%$ & $\mathbf{n}$ & $\%$ & $\mathbf{n}$ & $\%$ & $\mathbf{n}$ & $\%$ & & \\
\hline \multicolumn{19}{|l|}{ Cinsiyet } \\
\hline Kadın (147) & 1 & 1,2 & 82 & 98,8 & 3 & 27,3 & 8 & 72,7 & 3 & 5,7 & 50 & 94,3 & 7 & 4,8 & 140 & 95,2 & 0,97 & 0,755 \\
\hline Erkek (173) & 2 & 2,0 & 99 & 98,0 & 3 & 50,0 & 3 & 50,0 & 2 & 3,0 & 64 & 97,0 & 7 & 4,0 & 166 & 96,0 & & \\
\hline \multicolumn{19}{|l|}{ Yaş grubu } \\
\hline$<15(6)$ & 0 & 0,0 & 4 & 100,0 & 0 & 0,0 & 1 & 100,0 & 0 & 0,0 & 1 & 100,0 & 0 & 0,0 & 6 & 100,0 & & \\
\hline $16-26(37)$ & 0 & 0,0 & 20 & 100,0 & 0 & 0,0 & 1 & 100,0 & 0 & 0,0 & 16 & 100,0 & 0 & 0,0 & 37 & 100,0 & & \\
\hline $27-37(92)$ & 0 & 0,0 & 44 & 100,0 & 2 & 33,3 & 4 & 66,7 & 3 & 7,1 & 39 & 92,9 & 5 & 5,4 & 87 & 94,6 & & \\
\hline $38-48(70)$ & 2 & 4,5 & 42 & 95,5 & 1 & 33,3 & 2 & 66,7 & 1 & 4,3 & 22 & 95,7 & 4 & 5,7 & 66 & 94,3 & - & - \\
\hline $49-59(73)$ & 1 & 2,1 & 46 & 97,9 & 1 & 33,3 & 2 & 66,7 & 1 & 4,3 & 22 & 95,7 & 3 & 4,1 & 70 & 95,9 & & \\
\hline $60-70(33)$ & 0 & 0,0 & 19 & 100,0 & 2 & 66,7 & 1 & 33,3 & 0 & 0,0 & 11 & 100,0 & 2 & 6,1 & 31 & 93,9 & & \\
\hline $71>(9)$ & 0 & 0,0 & 6 & 100,0 & 0 & 0,0 & 0 & 0,0 & 0 & 0,0 & 3 & 100,0 & 0 & 0,0 & 9 & 100,0 & & \\
\hline
\end{tabular}

*P: Pozitif N: Negatif 
2015-2019 yılları arasında araştırma kapsamına alınan hastaların Klinik HBV gruplarına göre anti HDV pozitifliğinin yıllara göre dağılımı ve anti HDV pozitifliğinin yıllara göre karşılaştırılmasına ilişkin ki kare testi sonuçları Tablo 2'de verilmiştir. Hastaların yıllara göre anti HDV pozitifliği oranları arasında istatistiksel olarak anlamlı düzeyde bir fark olmadığ $\breve{1}_{1}$ tespit edilmiştir $(\mathrm{p}>0,05)$ (Tablo 2).

Tablo 2. Klinik HBV Gruplarında Anti HDV Pozitifliğinin Yıllara Göre Dağılımı (2015-2019)

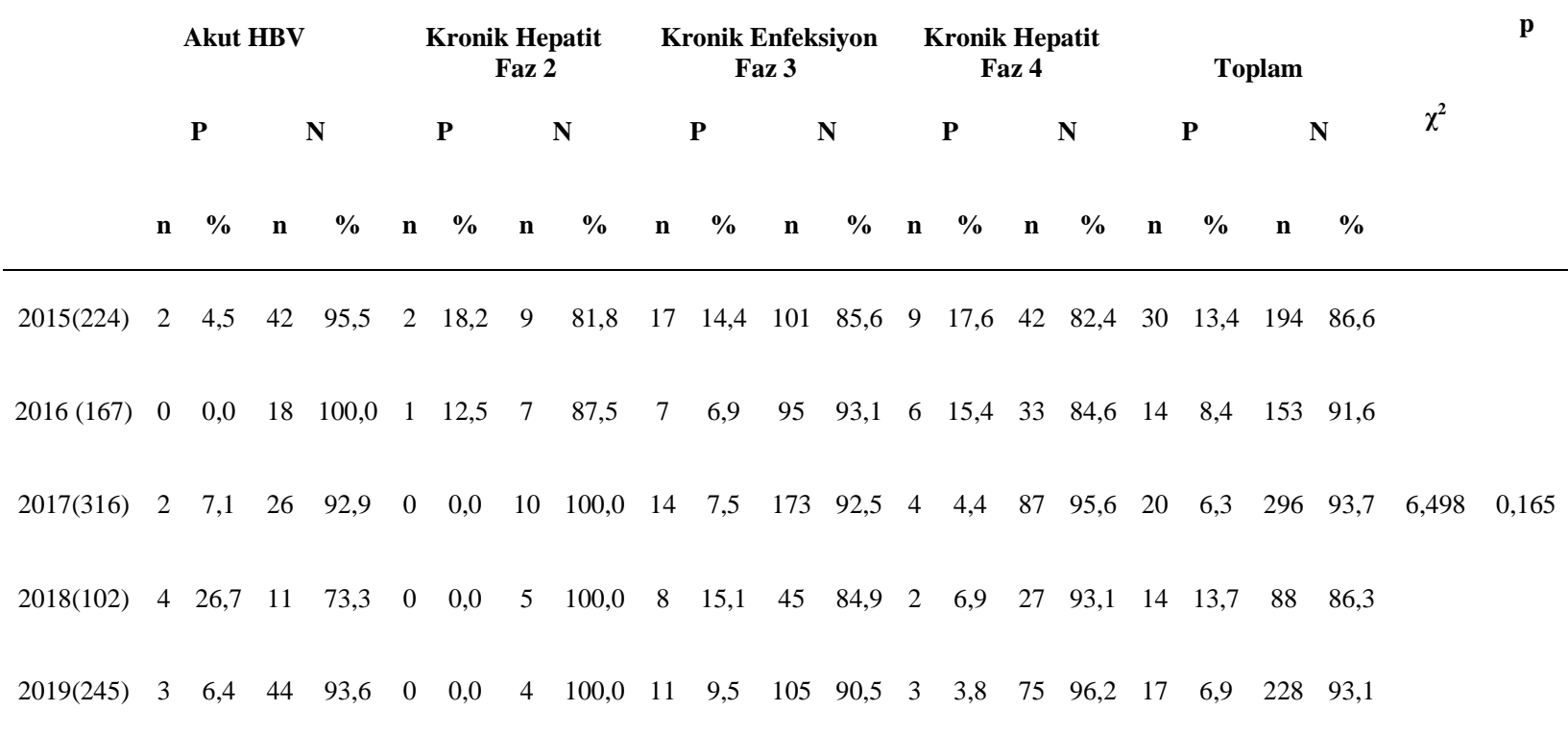

*P: Pozitif N: Negatif

2015-2019 yılları arasındaki hastaların klinik HBV gruplarında anti HDV pozitifliğinin cinsiyete göre dağılımı ve klinik HBV gruplarında anti HDV pozitifliğinin karşılaştırılmasına ilişkin $\mathrm{Ki}$ kare testi bulguları Tablo 3'de gösterilmiştir. Cinsiyete göre klinik HBV gruplarında anti HDV pozitifliği oranları arasında istatistiksel olarak anlamlı düzeyde bir fark olmadığ saptanmıştır ( $>00,05)$ (Tablo 3).

Tablo 3. Klinik HBV Gruplarında Anti HDV Pozitifliğinin Cinsiyete Göre Dağılımı (2015-2019)

\begin{tabular}{lcccccc}
\hline \multicolumn{1}{c}{ Klinik HBV Grupları (n) } & \multicolumn{7}{c}{ Anti HDV } & & \\
& \multicolumn{2}{c}{ Pozitif } & \multicolumn{2}{c}{ Negatif } & $\chi^{\mathbf{2}}$ & p \\
\hline Akut HBV (152) & n & \% & n & \% & & \\
Kadın (62) & 11 & 7,2 & 141 & 92,8 & & \\
Erkek (90) & 6 & 9,7 & 56 & 90,3 & & \\
Kronik Hepatit (326) & 5 & 5,6 & 85 & 94,4 & & \\
Kadın (128) & 27 & 8,3 & 299 & 91,7 & & \\
Erkek (198) & 16 & 12,5 & 112 & 87,5 & 1,344 & \\
Kronik Enfeksiyon (576) & 11 & 5,6 & 187 & 94,4 & & \\
Kadın (248) & 57 & 9,9 & 519 & 90,1 & & \\
Erkek (328) & 31 & 12,5 & 217 & 87,5 & & \\
\end{tabular}

2015-2019 yılları arasındaki hastaların klinik HBV gruplarında anti HDV pozitifliğinin yaş gruplarına göre dağılımı Tablo 4'de gösterilmiştir. Hastaların yaş gruplarına göre anti HDV pozitifliği oranları arasında istatistiksel olarak anlamlı düzeyde bir fark olmadığ 1 saptanmıştır ( $\mathrm{p}>0,05)$ (Tablo 4). 
Tablo 4. Klinik HBV Gruplarında Anti HDV Pozitifliğinin Yaş Gruplarına Göre Dağılımı (2015-2019)

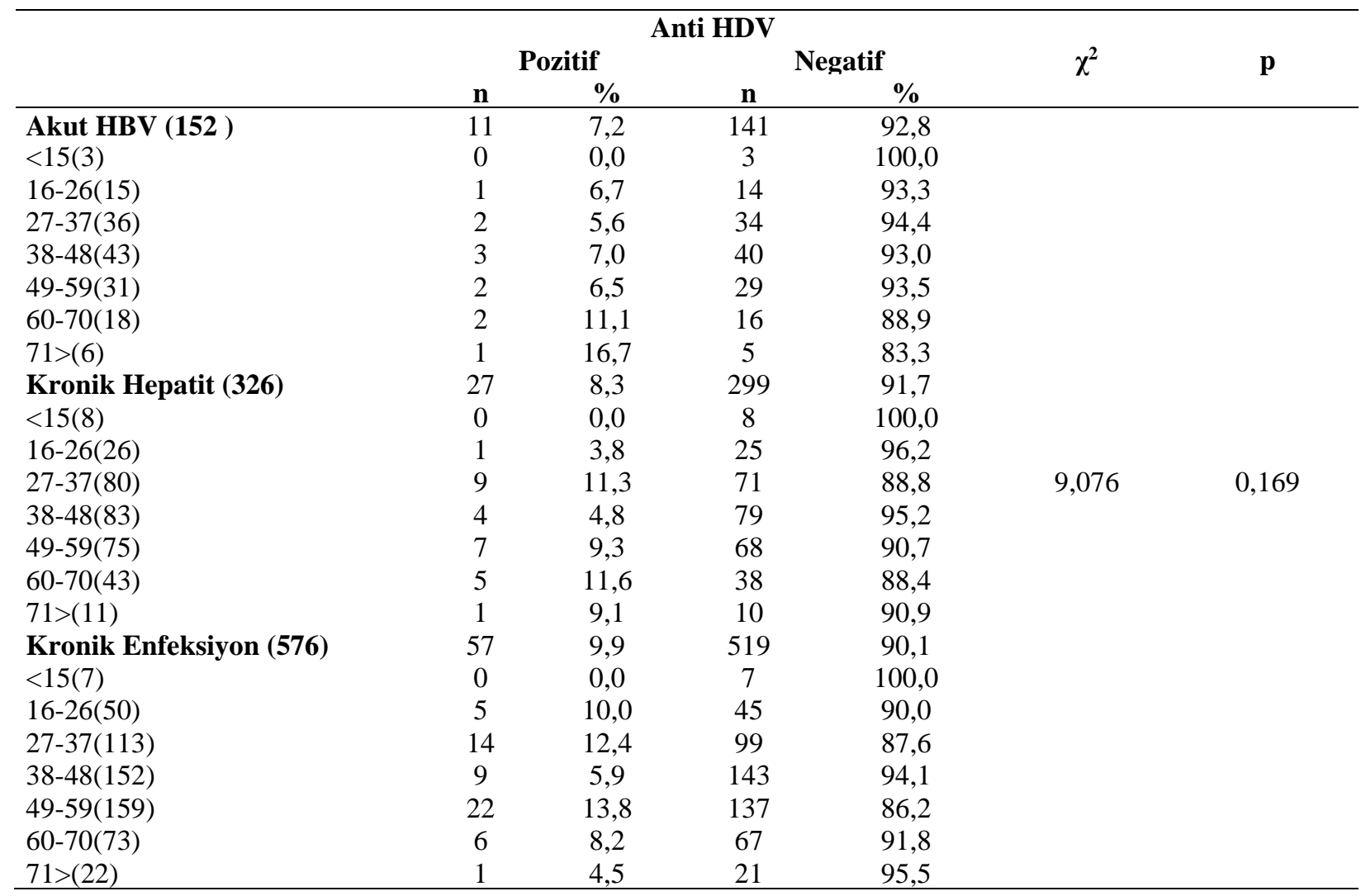

2014-2019 yılları arasındaki hastaların Anti HDV pozitifliğinin yaş ve cinsiyete göre dağılımı ve karşılaştırılmasına ilişskin Ki kare testinden elde edilen bulgular Tablo 5'de gösterilmiştir. Tablo 5.'e göre kadın ve erkek bireylerde Anti HDV pozitifliği oranları arasındaki farkın istatistiksel olarak anlamlı düzeyde olduğu belirlenmiştir $(\mathrm{p}<0,05)$. Kadın bireylerde Anti HDV pozitifliği, erkeklere göre anlamlı düzeyde yüksek bulunmuştur. Yaş gruplarına göre anti HDV pozitifliği oranları arasında istatistiksel olarak anlamlı düzeyde bir fark bulunmadığ 1 saptanmıştır ( $\mathrm{p}>0,05)($ Tablo 5).

Tablo 5. Anti HDV Pozitifliğinin Yaş ve Cinsiyete Göre Dağılımı (2014-2019)

\begin{tabular}{|c|c|c|c|c|c|c|}
\hline \multicolumn{7}{|c|}{ Anti HDV } \\
\hline & \multicolumn{2}{|c|}{ Pozitif } & \multicolumn{2}{|c|}{ Negatif } & \multirow{2}{*}{$\chi^{2}$} & \multirow[t]{2}{*}{$\mathbf{p}$} \\
\hline & $\mathbf{n}$ & $\%$ & $\mathbf{n}$ & $\%$ & & \\
\hline \multicolumn{7}{|c|}{ Cinsiyet } \\
\hline Kadın (585) & 60 & 10,3 & 525 & 89,7 & \multirow{2}{*}{7,529} & \multirow{2}{*}{$0,004 *$} \\
\hline Erkek (789) & 49 & 6,2 & 740 & 93,8 & & \\
\hline \multicolumn{7}{|l|}{ Yaş grubu } \\
\hline$<15(24)$ & 0 & 0,0 & 24 & 100,0 & \multirow{7}{*}{8,816} & \multirow{7}{*}{0,184} \\
\hline $16-26(128)$ & 7 & 5,5 & 121 & 94,5 & & \\
\hline $27-37(321)$ & 30 & 9,3 & 291 & 90,7 & & \\
\hline $38-48(348)$ & 20 & 5,7 & 328 & 94,3 & & \\
\hline $49-59(338)$ & 34 & 10,1 & 304 & 89,9 & & \\
\hline $60-70(167)$ & 15 & 9,0 & 152 & 91,0 & & \\
\hline $71>(48)$ & 3 & 6,3 & 45 & 93,8 & & \\
\hline
\end{tabular}




\subsection{Tartışma}

HDV, HBV enfeksiyonlarında siroz ve hepatoselüler karsinom riskini arttıran önemli bir viral hepatit formudur. Dünyanın tüm coğrafik bölgelerinde görülebilen HDV enfeksiyonu, coğrafik ve sosyokültürel farklılıklar nedeni ile heterojen dağılım göstermektedir[6]. Dünyada HBV enfekte hastaların \%5'i HDV ile ko-enfektedir. HDV enfeksiyonu, Akdeniz ülkeleri, Doğu Avrupa, Batı ve Güney Pasifik Adaları, Ortadoğu, Orta Asya, Orta ve Batı Afrika ve Güney Amerika gibi bölgelerde insanlar arasında yakın temas olması nedeni ile endemik olarak görülmektedir. Avrupa ülkelerinde HDV sıklığı kademeli olarak azalış eğilimi gösterirken halen kötü hijyen koşullarına sahip olan ülkelerde ağır enfeksiyonlar bildirilmektedir [6, 8, 10].

Kuzey Afrika'da 7 ülkeye ait(Misır, Tunus, Sudan, Moritanya, Cezayir ve Libya) 312 çalışmanın sonuçlarının irdelendiği bir meta analizde genel populasyına ait HDV prevalansı \%5.01 bulunurken, karaciğer hastalığ 1 olanlarda ise $\% 20.7$ bulunmuştur[12]. Küresel prevalansın belirlenmesi için 2020 yılında yapılan, 95 ülkeyi içeren 282 çalışmanın irdelendiği metaanalizde tüm HBsAg pozitif bireylerin \%4.5'inde, hepatoloji kliniğine başvuranların ise \%16.4'ünde antiHDV pozitifliği saptanmıştır. Metaanaliz sonuçları 1şı̆̆ında dünyada yaklaşık 12 milyon kişinin HDV enfeksiyonu olduğu belirlenmiştir. Buna göre; HBsAg pozitif genel populasyonun Afrika'da \%5.97'sinde, Amerika'da \%5.91'inde, Doğu Akdeniz ülkelerinin \%3.54'ünde, Avrupa'nın \%3'ünde, Doğu-Batı Asya'nın $\% 3.2$ 'sinde ve Batı pasifik ülkelerin \%4.09'unda, Türkiye'de ise \%2-5 arasında olduğu belirlenmiştir[13]. Türkiye, HDV enfeksiyonu açısından orta endemik kuşak içerisinde yer alan bölgelerden birisidir. Ülkenin doğu ve batı bölgeleri arasında yapılan analizlerde farklı prevalans sonuçları bildirilmektedir. Son yıllarda dünya verileri ile birlikte ülkemizde de HDV enfeksiyon prevalansında düşüş gözlense de doğu bölgesindeki pozitiflik batı bölgesine göre halen önemini korumaktadır [6, 10,14].

Ülkemizde Değertekin ve ark.'nın HDV prevalansı ile ilgili geniş kapsamlı değerlendirme yaptıkları bir metaanalizde anti-HDV pozitiflik oranları İstanbul'un da içinde bulunduğu Batı bölgesinde \%4.8, Güneydoğu Anadolu bölgesinde ise \%27.1 saptanmıştır[15]. Türkiye'de 2008-2011 yılları arasında Türk Karaciğer Araştırmaları Derneği tarafından geniş ölçekli yapılan epidemiyoloji çalışmasında 23 bölgenin köy ve kent populasyonlarından toplanan 5471 kişinin \%2.7'sinde anti-HDV pozitifliği saptanmıştır[16]. 2013 yılında Türkiye'nin 15 merkezinden elde edilen HBsAg'si pozitif saptanan 7366 hastada anti HDV \%4.5 oranında saptanmıştır[17]. 2015 yılında yine Türkiye nüfusunu temsilen 5460 kişide yapılan araştırma sonucunda HBsAg'si pozitif bulunan 218 kişinin \%2.8'inde anti HDV pozitif bulunmuştur[18]. Türkiye'de Sağlık
Bakanlığı Viral Hepatiti Önleme Programı 2018-2023'ün istatistiki verilerine göre ise Türkiye'de 1995 öncesi ve sonrası veriler kıyaslandığında kronik Hepatit B ve sirozlu olgularda hepatit delta prevalansının ülke genelinde azalma gösterdiği ve Batı Anadolu'da \%38'den \%20'ye düştüğü saptanmıştır[10]. Çalışmamızda HBV ve/veya HDV enfeksiyon şüphesi ile laboratuvarımıza başvuran $1374 \mathrm{HBsAg}$ 'si pozitif olan hastada \%7.9 oranında anti HDV pozitifliği saptanmıştır. $\mathrm{Bu}$ sonuç Türkiye temsili çalışma verileri ile yakın bulunmuş ancak batı bölgesindeki prevalansın yükseliş eğiliminde olduğu sonucuna varılmıştır.

Güdücüoğlu ve arkadaşlarının 2006 yılında 184 HBsAg pozitif hasta ile yürüttükleri çalışmada; 39 akut HBV'li olgunun \%7.7'sinde, 145 kronik HBV'li olgunun \%24.8'inde anti HDV pozitifliği saptanmıştır[19]. Güney doğu bölgesinde Çelen ve ark.'nın yapmış olduğu çalışmada asemptomatik taşıyıcıların \%6'sında, kronik vakaların ise \%27.5'inde anti HDV pozitif saptanmıştır[20]. Türkiye'nin batı bölgesinde yapılan araştırmada antiHDV pozitifliği $\% 2.5$ oranında saptanırken, 2011 yılında İstanbul'dan bildirilen farklı bir araştırmada ise $\% 7$ oranında anti-HDV pozitifliği bildirilmiştir[21,22]. Son y1llarda uygulanan etkili HBV aşılaması ile HDV enfeksiyonunun görülme sıklığının azalış eğiliminde olduğu bildirilse de, Marmara merkezli İstanbul bölgesine ait prevalans verilerimiz beklenilenin aksine bu bölgede az da olsa yükseliş göstermiştir. $\mathrm{Bu}$ yükselişin Marmara merkezli kozmopolit şehir olan İstanbul'un sık iç ve dış göç alması, göçlerle birlikte aşısız ve duyarlı insanların topluma karışması, toplumda sosyoekonomik ve kültürel değişimlerin ortaya çıkması, korunmasız cinsel ilişki ve madde bağımlılı̆̆ının artış göstermesi gibi nedenlere bağlı olarak geliştiği kanaatindeyiz.

2011 yılında İzmirli ve ark'nın Marmara merkezli İstanbul'da yapmış oldukları benzer çalışmada HBsAg pozitif 6707 kişinin \%4.5'inde, akut HBV'li olguların \%3.2'sinde, kronik HBV'li olguların \%4.4'ünde ve asemptomatik kişilerin \%5.1'inde anti HDV pozitif saptanmıştır[23]. İzmir'de Yursever ve ark'nın yaptığ çalışmada kronik Hepatit B olgularında \%6.3 oranında anti-HDV pozitifliği saptanırken[24], 2012 yılında Ankara'da yapılan benzer çalışmada $348 \mathrm{HBsAg}$ pozitif hastanın \%2'sinde, HBsAg taşıyıcılığı olanların $\% 2.6$ 'sında, kronik olguların \%0.6'sinda ve sirozu bulunan vakaların \% 7.3'ünde anti-HDV pozitifliği tespit edilmiştir[25]. Ağrı'da $787 \mathrm{HBsAg}$ pozitif hasta ile yapılan araştırmada \%7, Elazığ'da 2018 yılında yapılan benzer çalışmada 554 HBV enfeksiyonu bulunan bireylerin \%9.6'sında, 2019 yılında yine ayni bölgede 250 kronik hepatitli bireyin \%9.6'sında, 205 kronik enfeksiyonu olan bireyin \% 7.8 'inde antiHDV pozitifliği tespit edilmiştir[5, 15, 26].

5 yıllık verilerin incelendiği çalışmamızda; 2015-19 yılları arasındaki hastalar klinik HBV durumlarına göre 
Avrupa Karaciğer Araştırmaları Derneği'nin 2017 Klinik Uygulama Kılavuzunda belirtilen şekilde değerlendirmeye alınmış ancak 2014 yılına ait hastaların HBV DNA verilerine ulaşılamadığından ötürü bu hastalar serolojik, ALT düzeyi ve karaciğer histolojisine göre kategorilere ayrılmıştır. Çalışmamıza dahil edilen 2014 yılına ait 184 Akut HBV'li hastanın \%1.6'sınde, 17 kronik HBV'li hastanın \%35.2'sinde ve 119 inaktif taşıyıcı olan hastanın ise \%4.2'sinda anti HDV pozitifliği saptanmıştır. 2015-2019 yıllarına ait veriler incelendiğinde 152 Akut HBV'li hastanın \%7.2'sinde, 326 kronik hepatitli hastanın \%8.3'ünde ve 576 kronik enfeksiyonlu hastanın \%9.9'unda anti HDV pozitifliği saptanmıştır.

Ulusal düzeyde yapılan bir çok literatür verisi ile parallel olarak çalışmamızda süperenfeksiyon oranının koenfeksiyona göre daha yüksek olduğu saptanmıştır[20, 21]. Her ne kadar süperenfeksiyon verilerimiz Güdücüoğlu ve Çelen'in bulgularına göre düşük bulunsa da[20, 21], 2011 yılında İstanbul bölgesinde çalışmamız ile ayni merkez ve ayni birimden yapılan İzmirli ve ark'nın çalışma bulgularına göre dikkat çekici şekilde yüksek bulunmuştur[23].

Ülkemizde yapılan epidemiyolojik çalışmalarda cinsiyet ile HDV seroprevalansı arasında istatistiksel olarak ilişki olmadığ 1 bildirilmiş olsa da Şahin, Doğan, Altınbaş ve Karlıdağ'ın çalışmalarında HDV enfeksiyonunun erkeklerde kadınlara göre daha yüksek oranda saptandığı, buna karşın 2011 yılında çalışmamız ile ayni merkezden yapılan İzmirli ve ark'nın çalışmasında ise kadınlarda erkeklere göre daha yüksek bulunduğu bildirilmiştir[5, 22, 23, 25, 26]. Literatür verilerinden farklı olarak çalışmamızda klinik HBV olgularında anti HDV pozitifliği kadın olgularda erkek olgulara göre istatistiksel olarak anlamlı derece yüksek bulunmuştur. $\mathrm{Bu}$ sonuç; her ne kadar cinsiyetler arasında istatistiksel olarak anlamlı farklılık bulunmasa da, ayni merkezden yapılan İzmirli ve ark'nın çalışma bulgularına benzerlik gösterirken, Şahin, Doğan, Altınbaş ve Karlıdağ'ın çalışma bulgularına göre farklı bulunmuştur. Sonucumuzun literatür verilerinden farklılık göstermesinin, hastaların farklı tarihlerde, farklı coğrafi bölgelerden ve tesadüfi olarak hastaneye başvurmalarından kaynaklandığı düşünülmektedir.

Yaş gruplarına göre anti-HDV pozitifliğinin dağılımı incelendiğinde istatistiksel olarak yaş grupları arasında anlamlı düzeyde fark bulunmadığı ancak erişkin orta yaş grubunda gençlere göre daha yüksek düzeyde olduğu belirlenmiştir. Çalışmamızda $<15$ yaş altı çocukların hiç birinde, 16-26 yaş arası gençlerde ise diğer yaş gruplarına göre daha düşük oranda Anti HDV pozitifliği saptanmıştır. Bu sonuç, Türkiye'de 1998 yılından itibaren Hepatit B aşısının rutin, doğumdan itibaren uygulanmasına bağlı olarak ortaya çıkmıştır. Araştırmamızda 49-59 yaş aralığında anti HDV pozitifliğinin diğer yaş gruplara kıyasla daha yüksek olduğu belirlenmiştir. İzmirli'nin İstanbul bölgesinde çalışmamız ile ayni merkezde yaptığı çalışmasında antiHDV pozitifliği 38-48 yaş aralığında en fazla görülürken[23], benzer bölgede yapılan Yaşar'ın çalışmasında ise en yoğun 25-45 yaş aralığında saptanmıştır[22].

2014 yilında hastanemize HBV ve/veya HDV enfeksiyon şüphesi ile başvuran hastalara ait $\mathrm{HBV}$ DNA test sonuçlarının hiçbirine elektronik ortamda ulaşılamamıştır. $\mathrm{Bu}$ durum, elektronik kayıt sistem bilgilerinin çeşitli sebepler ile eksik olduğunun bir göstergesidir. Öte yandan 2014-2019 yılları arasında hastanemize HBV ve/veya HDV enfeksiyon şüphesi ile başvuran hastalardan 109'unun anti HDV'si pozitif saptanmış ancak yine kayıt sisteminde bunların 84'ünün HDV RNA sonuçlarına ulaşılabilmiştir. $\mathrm{Bu}$ durumun elektronik kayıt sisteminde eksik veya hastaların farklı merkezlerde test yaptırmasına bağlı olarak gelişebileceği düşünülmektedir. Ancak anti HDV'si pozitif bulunan 84 hastanın tamamının sonuçlarının RNA ile uyumlu ve korele olduğu belirlenmiştir. HBV DNA ve HDV RNA verilerine elekronik kayıt sisteminde ulaşılamaması çalışmamızın sınırlılığı olarak değerlendirilmiştir.

\section{Sonuc}

Çalışma sonuçlarımız, Marmara merkezli İstanbul bölgesinden retrospektif olarak bildirilen prevalans çalışmalarına yakın bulunmakla birlikte, anti HDV prevalansının beklenenin tersine az da olsa yükseliş eğiliminde olduğunu göstermektedir. Olgu sayılarındaki yükselişin; Marmara merkezli İstanbul'un insan hareketlerinin çok olduğu metropol bir şehir olması, son yıllarda farklı kültürlerden iç ve dış sık göç alması ve buna bağlı olarak toplumda sosyoekonomik ve kültürel değişimlerin ortaya çıkması, madde bağımlılığı ve korunmasız cinsel ilişkideki artışa bağlı olarak ortaya çıktığı kanaatindeyiz. Toplumun bulaş yollarına karşı bilinçlendirilmesi ve kampanyalar şeklinde duyarlı bireylere aşı uygulamalarının yapılması ile birlikte bu yükselişin önüne geçilebileceği düşünülmektedir. Ayrıca HBV enfeksiyonunun HDV ile ilişkili olması ve HDV enfeksiyonun klinik tabloya ağırlaştırıcı etki etmesi sebebi ile ülkemizdeki güncel prevalans verilerinin oluşturulabilmesi için geniş çaplı çalışmalar yapılmasının ve HBV olgularda izlem stratejilerinin geliştirilmesi gerektiğini düşünmekteyiz.

\section{Referanslar}

1. Rizetto, M, Canese, M.G, Arico, S, Crivelli, O, Trepo, C, Bonino, F. et el, Immunofluorescencedetection of new antigen-antibody system(delta/antidelta) associated to hepatitis B virus in liver and serum of HBsAg carriers, Gut, 1977, 18(12), 997-1003.

2. Us, D, Ergünay, K, Moleküler, Tanısal ve Klinik Viroloji, Bilimsel Tip Yayınevi, Ankara, 2012.

3. Wedemeyer, H, Manns, M.P, Epidemiology, pathogenesis and management of hepatitits D:uptade and chanlenges ahead, Nature Reviews. Gastroenterology ogy Hepatol, 2010, 7(1), 31-40.

4. Romeo, R, Role of the hepatitits Delta virus on the pathogenesis of hepatic cirrhosis and hepatocellular carcinoma, Recent advances, Recenti Progressi in Medicina, 2010, 101, 52-56. 
5. Şahin, A, Gürocak, S, Tunç, N, Demirel, U, Poyrazoğlu, O.K, Anti HDV seroprevalance among patients with previous HBV infection, Northern. Clinics of İstanbul, 2018, 5(2), 132-138.

6. Tosun, S, Hepatit delta virus enfeksiyonu epidemiyolojisinde değişim ve ülkemizdeki güncel durum, Ankem Dergisi, 2013, 27 128-134.

7. World Health Organisation(WHO), Global Hepatitis Report, 2017

8. Tülek, N, Hepatit D: Viroloji, epidemiyoloji, patogenez, Klimik Hepatit Akademisi, Hatay, 2016.

9. Rizetto, M, Hepatitis D virus: Introduction and Epidemiology, Cold Spring Harbor Perspectives Medicine, 2015, 5(7), a021576.

10. T.C. Sağlık Bakanlığı, Türkiyede Viral Hepatit Önleme Programi 2018-2023.

11. European Association for the Study of the Liver, EASL 2017 Clinical Practice Guidelines on the management of hepatitis B virus infection, Journal of Hepatology, 2017, 67(2), 370-398.

12. Daw, M.A, Daw, A.M, Sifennasr, N.E.M, Draha, A.M et al., The epidemiyology of Hepatitis D virus in North Africa: A systematic Review and Meta Analysis, The Scientific World Journal, 2018(Article ID: 9312650), 1-11.

13. Stockdale, A, Kreuels, B, Henrion, M.Y.R, Giorgi, E, Kyomuhangi, I. et al., The global of hepatitis D virus infection: Systemic review and meta analysis, Journal of Hepatology, 2020, 73, 523-532

14. Doğan, M, Güneş, H, Mete, R, Taş, T, Mengeloğlu, F.Z Küçükbayrak, A. Kronik Hepatit B enfeksiyonlu hastalarda anti HDV ve HDAg prevalans1, Dicle Tip Dergisi, 2013, 40(1), 50-53.

15. Değertekin, H, Yalçın, K, Yakut, M, Yurdaydin, C, Seropositivity for delta hepatitis in patients with chronic hepatitis B and liver cirrhosis in Turkey: a meta analysis, Liver International, 2008, 28(4), 494498.

16. Tözün, N, Özdoğan, O, Çakaloğlu, Y, İdilman, R, et al., A Nationwide Prevalance Study and Risk Factors for Hepatitis A, B,C and D infections in Turkey. The 61st Annual Meeting of the American Association for the Study of Liver Diseases: The Liver Meeting 2010, Hepatology, 2010, 52, 697.

17. Ayaz, C, Tekin, S.K, Yalc1, A, Yamazhan, T, Aygen, B., Epidemiology and risk factors of hepatitis delta infection in Turkey, Journal of Pure and Applied Microbiology, 2013, 7(4), 2809-2813.

18. Tozun, N, Ozdogan, O, Cakaloğlu, Y, İdilman, R, Karasu, Z, Akarca, U, Kaymakoglu, S, Ergonul, O, Seroprevalance of hepatitis b and c virus infections and risk factors in Turkey: a fieldwork TURHEP study, Clinical Microbiology and Infection, 2015, 21(11), 10201026 .

19. Güdücüoğlu, H, Altunbaş, S, Bozkurt, H, Baykal, S, Berktaş, M, Van Askeri Hastanesinde HBsAg pozitif askerlerde delta antikorunun araștırılması, Van Tip Dergisi, 2006, 13, 118-120.

20. Çelen, M.K, Ayaz, C, Hosoğlu, S, Geyik, M.F, Ulug, M, Ant hepatitis delta virus seroprevalance and risk factors in patients with hepatitis B in South-east Turkey, Saudi Medical Journal, 2006, 27(5), 617-620.

21. Kose, S, Ece, G, Gozaydın, A, Turken M., Study on seroprevalance of hepatitis delta in a regional hospital in western Turkey, Journal of Infection in Developing Countries, 2012, 6(11), 782-785.

22. Yaşar, K.K, Pehlivanoglu, F, Şengöz, G, Sekiz aylık dönemde laboratuvarımızda saptanan hepatit B ve hepatit D seroprevalans1, Viral Hepatit Dergisi, 2011, 17(1), 22-26.

23. İzmirli, S, Çelik, D.G, Güngördü, Z, Ziver, T, Aslan, M, Sarıbaş, S, Çalışkan, R ve ark., Hepatit Delta Virüsü ,infeksiyonu seroprevalansi: retrospektif temelli seroepidemiyolojik bir değerlendirme, Flora, 2011, 16(3), 120-126.

24. Yurtsever, S.G, Er, H.H, Güngör, S,Uzun, B, Hepatit B virus enfeksiyonunda delta antikor sıklığı ve klinik önemi, Viral Hepatit Dergisi, 2011, 17, 69-73.

25. Altınbaş, A, Yılmaz, B, Ekiz, F, Aktaş, B, Çoban, Ş, Başar, Ö, Yüksel, O, HBsAg pozitif hastalarda delta hepatit seropozitiflik sıklığı, Cumhuriyet Tip Dergisi, 2012, 34, 56-59.

26. Karlıdağ, G.E, Kronik Hepatit B hastalarında Hepatit Delta sıklığı, Klimik Derg, 2019, 32(3), 281-284.

http://edergi.cbu.edu.tr/ojs/index.php/cbusbed isimli yazarın CBU-SBED başlıklı eseri bu Creative Commons Alıntı-Gayriticari4.0 Uluslararası Lisansı ile lisanslanmıştır. 